\title{
Effect of Irrigation Canal Sediments, Humate Fertilizer and Irrigation Interval on Wheat Performance in Desert Soils
}

\author{
By Ali Abdalla Mohammed ", Asim Osman Elzubeir ${ }^{\dagger}$, \\ Muawia Elbedawi Hamad ${ }^{*}$ \& Abdalla Ibrahim Elhagwa
}

A field study was conducted for two successive winter seasons; 2013/14 and 2014/15, at the Research Farm of the National Institute of Desert Studies (University of Gezira), New Hamdab Scheme, Northern State of Sudan. The objective was to investigate the effect of treatments interactions of application of irrigation canal sediments, humate fertilizer and irrigation interval on wheat (Triticum aestivum L.) growth and yield attributes in high terrace soils. Treatments were arranged in a split-split plot design with four replicates. Application of irrigation canal sediments constituted three rates $(0,30$ and 60 ton/ha), three rates of humate fertilizer were used $(0,2$ and $4 \mathrm{~kg} / \mathrm{fed})$ and two levels of irrigation interval were imposed (10 and 15 days). The soil of the experimental site is characterized by high amount of sand and low chemical soil fertility and the climatic zone of the area is described as desert. The results showed significant differences $(P \leq 0.05)$ due to the interactions effect of these three factors on number of plants $/ \mathrm{m}^{2}$, plant height, number of spikes $/ \mathrm{m}^{2}$, number of seeds/spike, 1000-seeds weight, grain yield and straw yield for both seasons. Also, treatments interactions had highly significant effects $(P \leq 0.01)$ on number of tillers $/ \mathrm{m}^{2}$ and harvest index, and very highly significant differences $(P \leq 0.001)$ on biological yield of wheat in both seasons. The best combination of irrigation canal sediments, humate fertilizer and irrigation interval which gave the highest values of growth, yield and yield components of wheat for both seasons; except for number of plants $/ m^{2}$ in the second season and straw yield in both seasons, was the interaction effect of application of 60 ton/ha irrigation canal sediments, $4 \mathrm{~kg} / \mathrm{fed}$ humate fertilizer and 10 days irrigation interval.

Keywords: Aridisols, Humic Substances, Irrigation Water Scheduling, Northern State (Sudan), Soil Reclamation, Triticum Aestivum L.

\section{Introduction}

Wheat (Triticum aestivum L.) is mainly grown in the Sudan under irrigation, during winter months; its cultivation has recently expanded into latitudes lower than $15^{\circ} \mathrm{N}$ (Ageeb et al. 1996, Almeu and Hazem 2011). Demand for wheat in the past was not very high because the nutritional habit of the majority of the Sudanese people was based mainly on sorghum. At present, wheat consumption has increased and the government is attempting to attain self-sufficiency in this commodity. In order to fulfill this objective, it is necessary to increase the

\footnotetext{
* National Institute of Desert Studies, University of Gezira, Sudan.

${ }^{\dagger}$ Professor, Faculty of Agricultural Science, University of Dongola, Sudan.

${ }^{\star}$ Faculty of Agricultural Sciences, University of Gezira, Sudan.

- Agricultural Research Corporation, Wad Medani, Sudan.
} 
cultivated area and obtain maximum output from each unit volume of water consumed.

Increasing wheat productivity is a national target in Sudan to fill the gap between wheat consumption and production. However, lack of yield stability over seasons and locations has remained a great challenge to both research and production management (Babiker and Faki 1994). Wheat production under semiarid conditions of Sudan is now a success. Grain yield of over five ton/ha were obtained with high irrigation, either from river flows or lifted from the River Nile and wells using diesel pumps (Farah et al. 1994).

New Hamdab Scheme (Northern State of Sudan) faces problems of mud accumulation in all irrigation canals. Enormous amounts of sediments are being removed during cleaning of these canals. Disposal of this sediment is a real problem. Sediments accumulated in irrigated canals contain high quantities of clay and might be a useful as a soil conditioner (Mubarak et al. 2014).

There is more interest in utilizing soils of low or marginal productivity (e.g., sandy soils) for crop production to match the demand for agricultural products (Tester 1990). The major constraints of these soils are their water retention, high water transmission and low nutrient content. The nutrients- poor sandy soils could be productive if their content of organic matter can be increased. The maintenance of proper soil organic matter levels to sustain soil productivity is important and humic acid probably being the largest single soil organic matter that may cope up with the objective.

In many of the arid and semi-arid regions in the world (including Sudan) water is likely to become the most critical resource and the most limiting factor of the production of food (Elquosy 1998). Also, Ageeb (1994) stated that, irrigation water and irrigation practices are factors which have always limited wheat productivity. Detection of crop water stress is critical for efficient irrigation water management, especially in the semi-arid regions. On the other hand, irrigation water is becoming increasingly scares; this highlights the importance of the effective and efficient use of this resource. In truly arid regions; such as the Northern State (Sudan), all water of crops must be met with irrigation. In these areas, all phases of crop production are adjusted for irrigation. Regardless of the method used to deliver water, irrigation must supply moisture to that part of the soil from which roots absorb it. The timing and amount of irrigation should be regulated to assure optimum crop yield.

Recent years have witnessed a great intensification of land and water use in an effort to increase agricultural production in many parts of the world. This involved application of modern techniques leading to an increased farming efficiency. Therefore, an experimental study was conducted at El Multaga area, Northern State (Sudan) under high terrace soils to evaluate the interaction effect of application of irrigation canal sediments, humate fertilizer and irrigation interval to improve wheat productivity in the area. 


\section{Materials and Methods}

\section{Description of the Experimental Site}

Field experiments were carried out during two consecutive winter seasons (2013/14 and 2014/15) at the National Institute of Desert Studies Research Farm (University of Gezira), New Hamdab Scheme, Northern State of Sudan which lies at latitude $17^{\circ} 55^{\prime} \mathrm{N}$ and longitude $31^{\circ} 10^{\prime} \mathrm{E}$. The climatic zone of the area is described as desert, which is characterized by high temperature in summer, low temperature in winter and low rainfall (Habiballa and Ali 2010). The soil of the experimental site belongs to El Multaga soil series, texture of the control section is fine loamy, its structure is strong wide columnar flat breaks into medium and fine subangular blocky. It is classified as Vertic Haplocambids, fine loamy, mixed, hyperthermic. Generally, the soil chemical fertility is low (Land and Water Research Centre 1999).

\section{Experimental Design and Treatments}

Three treatments were arranged in a split-split-plot design that completely randomized within four replicates. The experimental area for each replicate was divided into three blocks, each block was divided into two strip plots and each was further divided into three subplots. Three meters wide areas were left between blocks as buffer zones. The area of each sub- sub plot (experimental unit) was 42 $\mathrm{m}^{2}(6 \times 7 \mathrm{~m})$. The experimental units were two meter apart from each other, with a total number of 18 experimental units. The main plots were assigned to irrigation interval with two levels, the sub- plots were assigned to irrigation canal sediments application with three rates and sub- sub plots were assigned to humate fertilizer application with three rates. This setup was replicated four times. The experimental procedures were the same for both seasons. The applied treatments and their abbreviations are illustrated in Table 1. The experiment was part of research study to investigate the effects of applied treatments and their interactions on wheat performance and soil physical and chemical properties in the area.

Table 1. Treatments Application and their Abbreviations

\begin{tabular}{|c|c|c|}
\hline Treatment & Operation & Abbreviation \\
\hline \multirow{2}{*}{$\begin{array}{c}\text { Irrigation interval } \\
(\mathrm{I})\end{array}$} & 10 days & $\mathrm{I}_{1}$ \\
\cline { 2 - 3 } & 15 days & $\mathrm{I}_{2}$ \\
\hline Irrigation canal sediments \\
$(\mathrm{S})$ & 0 ton/ha & $\mathrm{S}_{1}$ \\
\cline { 2 - 3 } & $30 \mathrm{ton} / \mathrm{ha}$ & $\mathrm{S}_{2}$ \\
\cline { 2 - 3 } & $60 \mathrm{ton} / \mathrm{ha}$ & $\mathrm{S}_{3}$ \\
\hline \multirow{2}{*}{$\begin{array}{c}\text { Humate fertilizer } \\
(H)\end{array}$} & $0 \mathrm{~kg} / \mathrm{fed}$ & $\mathrm{H}_{1}$ \\
\cline { 2 - 3 } & $2 \mathrm{~kg} / \mathrm{fed}$ & $\mathrm{H}_{2}$ \\
\cline { 2 - 3 } & $4 \mathrm{~kg} / \mathrm{fed}$ & $\mathrm{H}_{3}$ \\
\hline
\end{tabular}

$\mathrm{I}_{1} \times \mathrm{S}_{1} \times \mathrm{H}_{1}=$ as the controlled treatments.

fed $=$ Feddan $(1 \mathrm{fed}=0.42 \mathrm{ha})$. 


\section{Cultural Practices}

The land after the site had been selected and before the application of the treatments, was freed from weeds and crop residues. The soil amendment materials; irrigation canal sediments, and humate fertilizer were spread at rates mentioned before, incorporated with the soil. Land preparation was done with tractor-mounted disc plough to ensure satisfactory seedbed. Also, site of study area was levelled to facilitate irrigation and ensure uniform soil moisture content distribution.

Wheat variety Wadi Elneel was used in this study. Sowing was done manually by digging on $20^{\text {th }}$ of November (winter season) for both agricultural seasons, with seed rate of $120 \mathrm{~kg} / \mathrm{ha}$, at $0.2 \mathrm{~m}$ inter-row spacing. Nitrogen and Phosphorus were added as recommended by Agricultural Research Corporation (Sudan). Harvest started when signs of maturity of wheat crop were observed. The crop was harvested on $21^{\text {st }}$ of March for both seasons. The irrigation was carried out every 10 and 15 days intervals; the ten days was considered the conventional practice, whereas the fifteen days was considered mild stress. According to Erneo (2007) who concluded that, wheat water requirements per season was $635 \mathrm{~mm}$, therefore, irrigation was applied with rate of $5.9 \mathrm{~mm} /$ day. Irrigation water was measured at the plot level by Parshall flume with its calibration curve. Water delivered to plots with constant water head. The source of water supply for farm irrigation system was River Nile.

\section{Collection of Data}

Plant samples were collected randomly from each experimental unit (sub- sub plot) and then growth and yield parameters were determined.

\section{Number of Plant $/ \mathrm{m}^{2}$}

Number of plants $/ \mathrm{m}^{2}$ were counted for each season at 10 days after sowing in three different positions in each sub- sub plot using a steel frame of one meter square. Then the mean number of plant $/ \mathrm{m} 2$ with respect to each treatment was calculated.

\section{$\underline{\text { Plant Height }}$}

Ten whole plant samples were selected randomly from each sub- sub plot at maturity stage, each season. Plant height as expressed in $\mathrm{cm}$ was measured from the tip of the spike to the soil surface, and then the mean was calculated.

\section{Number of Spike/m²}

Using steel frame of one meter square, the number of spikes $/ \mathrm{m}^{2}$ was calculated at harvest time for each sub- sub plot as an average number of three readings. 
Number of Tillers $/ \mathrm{m}^{2}$

Number of tillers $/ \mathrm{m}^{2}$ was obtained by subtracting the number of plants $/ \mathrm{m}^{2}$ at 10 days after sowing from the number of spikes $/ \mathrm{m}^{2}$ at harvest time, each season.

\section{$\underline{\text { Spike Length }}$}

Ten spikes samples were selected randomly from each sub- sub plot at maturity stage and the spike length $(\mathrm{cm})$ was measured, and then the mean spike length was obtained for each treatment.

\section{Number of Seeds/Spike}

Samples of ten spikes were selected randomly from each sub- sub plot at maturity stage and seeds per spike were counted, and then the mean number of seeds/spike was obtained.

\section{0 - Seeds Weight}

A number of thousand seeds were picked randomly from seeds of each subsub plot. The seeds were weighed with a sensitive balance, and mean 1000-seeds weight $(\mathrm{g})$ was obtained for each treatment.

\section{Biological Yield per Unit Area}

Plants of the net area of one meter square (using steel frame of one meter square) were cut at the soil surface at harvest time in three different positions in each sub- sub plot, tied in bundles and left to dry by air. After drying, the harvested plants were weighted to obtain the biological yield ( $\mathrm{kg} / \mathrm{ha})$ (dry matters plus grains).

\section{Grain Yield per Unit Area}

The biological yield samples were manually threshed and the grain yield as expressed in $\mathrm{kg} / \mathrm{ha}$ was obtained.

\section{$\underline{\text { Straw Yield per Unit Area }}$}

Also, straw yield ( $\mathrm{kg} / \mathrm{ha}$ ) was determined as mentioned by Imran (2010): Straw yield $(\mathrm{kg} / \mathrm{ha})=$ Biological yield $(\mathrm{kg} / \mathrm{ha})-$ Grain yield $(\mathrm{kg} / \mathrm{ha})$

\section{$\underline{\text { Harvest Index }}$}

Harvest index (\%) was obtained using the following formula (Imran 2010):

$$
\text { Harvest index }=\frac{\text { Total grain yield }(\mathrm{kg} / \mathrm{ha})}{\text { Total boilogical yield }(\mathrm{kg} / \mathrm{ha})} \times 100
$$




\section{Statistical Analysis and Interpretation of Data}

Statistical analysis was carried out using a computer software package (MSTAT). Significance of differences among the various characters under study was compared using Duncan's Multiple Range Test (DMRT). Results were presented in tabular forms.

\section{Results and Discussion}

Table 2 shows the mean values of number of plant $/ \mathrm{m}^{2}$ and plant height of wheat crop as affected by treatments interactions for both seasons. The results of the statistical analysis indicated that the interaction of irrigation interval, irrigation canal sediments and humate fertilizer had significant effects $(\mathrm{P} \leq 0.05)$ on number of plants $/ \mathrm{m}^{2}$ when checked early in both seasons. Since the number of plant $/ \mathrm{m}^{2}$ was counted at 10 days after sowing and at that time all experimental units had the same irrigation, therefore, the significant effect of the interaction of the applied treatments on number of plants $/ \mathrm{m}^{2}$ might be due to irrigation canal sediments and humate fertilizer. Also, the effect of interaction of irrigation interval, irrigation canal sediments and humate fertilizer on plant height at maturity stage was checked in both seasons. There were significant effects $(\mathrm{P} \leq 0.05)$ due to the interaction of these three factors on plant height in both seasons.

Table 2. The Mean Effect of Irrigation Interval, Irrigation Canal Sediments and Humate Fertilizer on Wheat Growth Parameters for Both Seasons

\begin{tabular}{|c|c|c|c|c|c|c|}
\hline \multirow{2}{*}{\multicolumn{3}{|c|}{$\begin{array}{c}\text { Treatment } \\
\text { combinations }\end{array}$}} & \multicolumn{2}{|c|}{ No. of plants $/ \mathrm{m}^{2}$} & \multicolumn{2}{|c|}{ Plant height (cm) } \\
\hline & & & $1^{\text {st }}$ Season & $2^{\text {nd }}$ Season & $1^{\text {st }}$ Season & $2^{\text {nd }}$ Season \\
\hline \multirow{9}{*}{$\mathbf{I}_{1}$} & \multirow{3}{*}{$\mathbf{S}_{1}$} & $\mathbf{H}_{1}$ & $181^{\mathrm{fg}}$ & $206^{\mathrm{i}}$ & $67^{e}$ & $72^{\mathrm{ef}}$ \\
\hline & & $\mathbf{H}_{2}$ & $183^{\mathrm{ef}}$ & $210^{\text {hi }}$ & $71^{\mathrm{d}}$ & $75^{\mathrm{de}}$ \\
\hline & & $\mathbf{H}_{3}$ & $184^{\mathrm{ef}}$ & $227^{f}$ & $74^{\mathrm{bc}}$ & $79^{\mathrm{bcd}}$ \\
\hline & \multirow{3}{*}{$\mathbf{S}_{\mathbf{2}}$} & $\mathbf{H}_{1}$ & $165^{i}$ & $234^{\mathrm{e}}$ & $72^{\mathrm{cd}}$ & $69^{\mathrm{fg}}$ \\
\hline & & $\mathrm{H}_{2}$ & $193^{\mathrm{d}}$ & $242^{\mathrm{d}}$ & $73^{\mathrm{cd}}$ & $80^{\mathrm{bc}}$ \\
\hline & & $\mathbf{H}_{3}$ & $197^{\text {bcd }}$ & $269^{a}$ & $74^{\mathrm{bc}}$ & $81^{\mathrm{bc}}$ \\
\hline & \multirow{3}{*}{$\mathbf{S}_{\mathbf{3}}$} & $\mathrm{H}_{1}$ & $187^{\mathrm{e}}$ & $210^{\mathrm{hi}}$ & $68^{\mathrm{e}}$ & $69^{\mathrm{fg}}$ \\
\hline & & $\mathbf{H}_{2}$ & $199^{\text {bcd }}$ & $234^{\mathrm{e}}$ & $76^{b}$ & $82^{b}$ \\
\hline & & $\mathbf{H}_{3}$ & $207^{\mathrm{a}}$ & $263^{\mathrm{b}}$ & $83^{\mathrm{a}}$ & $89^{\mathrm{a}}$ \\
\hline \multirow{9}{*}{$\mathbf{I}_{2}$} & \multirow{3}{*}{$\mathbf{S}_{1}$} & $\mathbf{H}_{1}$ & $201^{b}$ & $231^{\mathrm{ef}}$ & $53^{\mathrm{h}}$ & $60^{h}$ \\
\hline & & $\mathbf{H}_{2}$ & $206^{\mathrm{a}}$ & $219^{g}$ & $53^{h}$ & $59^{h}$ \\
\hline & & $\mathrm{H}_{3}$ & $196^{\mathrm{cd}}$ & $229^{\mathrm{ef}}$ & $61^{\mathrm{g}}$ & $67^{g}$ \\
\hline & \multirow{3}{*}{$\mathbf{S}_{2}$} & $\mathrm{H}_{1}$ & $172^{\mathrm{h}}$ & $247^{\mathrm{c}}$ & $49^{i}$ & $58^{\mathrm{hi}}$ \\
\hline & & $\mathbf{H}_{2}$ & $177^{\mathrm{g}}$ & $201^{j}$ & $55^{\mathrm{h}}$ & $54^{i}$ \\
\hline & & $\mathbf{H}_{3}$ & $168^{\text {hi }}$ & $211^{\text {hi }}$ & $62^{\mathrm{fg}}$ & $68^{\mathrm{fg}}$ \\
\hline & \multirow{3}{*}{$\mathbf{S}_{3}$} & $\mathrm{H}_{1}$ & $200^{\mathrm{bc}}$ & $221^{\mathrm{g}}$ & $53^{\mathrm{h}}$ & $58^{\text {hi }}$ \\
\hline & & $\mathrm{H}_{2}$ & $182^{f}$ & $212^{\mathrm{hi}}$ & $67^{\mathrm{e}}$ & $72^{\mathrm{ef}}$ \\
\hline & & $\mathbf{H}_{3}$ & $184^{\mathrm{ef}}$ & $219^{g}$ & $71^{\mathrm{d}}$ & $77^{\mathrm{cd}}$ \\
\hline & \multicolumn{2}{|c|}{ DMRT } & $*$ & $*$ & $*$ & $*$ \\
\hline
\end{tabular}

Abbreviations of I, $\mathrm{S}$ and $\mathrm{H}$ and their operations as explained in Table 1.

Means followed by the same letter(s) in column are not significantly different at $\mathrm{P} \leq 0.05$.

$*$ = Significantly different at $\mathrm{P} \leq 0.05$. 
Table 3 summarizes the mean effect of irrigation interval, irrigation canal sediments and humate fertilizer on wheat yield components parameters on both seasons. The results indicated that the interaction of these three factors had significant effects $(\mathrm{P} \leq 0.05)$ on number of spike $/ \mathrm{m}^{2}$, number of seeds/spike and 1000 -seeds weight in both seasons. The analysis of variances for both seasons evident that the number of tillers $/ \mathrm{m}^{2}$ was highly significantly affected $(\mathrm{P} \leq 0.01)$ by the interaction of the studied treatments. However, treatments interaction were failed to show any significant differences $(\mathrm{P} \leq 0.05)$ on spike length in the two seasons.

The mean values of wheat yield parameters as affected by the interactions of the applied treatments for both seasons are shown in Table 4. It was found that the interaction of the tested treatments showed very highly significant differences $(\mathrm{P} \leq$ 0.001 ) on biological yield in both seasons. Biological yield is a combined contribution of yield components such as number of tillers $/ \mathrm{m}^{2}$, plant height, number of seeds/spike and 1000-seeds weight. The biological yield is significantly charged by any change in these components. It was found that the interaction of irrigation interval, irrigation canal sediments and humate fertilizer had significant effects $(\mathrm{P} \leq 0.05)$ on grain yield and straw yield of wheat in both seasons. But, harvest index had highly significant differences $(P \leq 0.01)$ due to interaction effects of applied treatments in both seasons.

The results clarified that the application of $60 \mathrm{ton} / \mathrm{ha}$ of irrigation canal sediments and addition of $4 \mathrm{~kg} / \mathrm{fed}$ humate fertilizer when wheat was irrigated every ten days recorded the highest means values; compare to the controlled treatment and other treatments combinations, of all examined wheat growth and yield attributes in both seasons, except for number of plant $/ \mathrm{m}^{2}$ and straw yield which failed to show clearly the best combination of these three factors. Generally, the results showed highest values of the examined parameters of wheat crop in the second season than that of the first season. This could be attributed to the variations in climatic conditions between the two seasons, i.e. the second season was characterized by lower temperature in December and January and higher relative humidity percentage in all months compared to the first season, and the first season was characterized by higher temperature in February and March compared to the second season. High temperature is a major environmental constraint that limits wheat production in the Sudan (Ageeb 1994). Table 5 shows the mean temperature and relative humidity during growing seasons of wheat in both agricultural seasons as recorded by National Institute of Desert Studies Meteorological Station. 
Table 3. The Mean Effect of Irrigation Interval, Irrigation Canal Sediments and Humate Fertilizer on Wheat Yield Components Parameters on Both Seasons

\begin{tabular}{|c|c|c|c|c|c|c|c|c|c|c|c|c|}
\hline \multirow{2}{*}{\multicolumn{3}{|c|}{$\begin{array}{c}\text { Treatment } \\
\text { combinations }\end{array}$}} & \multicolumn{2}{|c|}{ No. of spikes $/ \mathrm{m}^{2}$} & \multicolumn{2}{|c|}{ No. of tillers $/ \mathrm{m}^{2}$} & \multicolumn{2}{|c|}{ Spike length $(\mathrm{cm})$} & \multicolumn{2}{|c|}{ No. of seeds/spike } & \multicolumn{2}{|c|}{ 1000-seeds weight (g) } \\
\hline & & & $1^{\text {st }}$ Season & $2^{\text {nd }}$ Season & $1^{\text {st }}$ Season & $2^{\text {nd }}$ Season & $1^{\text {st }}$ Season & $2^{\text {nd }}$ Season & $1^{\text {st }}$ Season & $2^{\text {nd }}$ Season & $1^{\text {st }}$ Season & $2^{\text {nd }}$ Season \\
\hline \multirow{9}{*}{$\mathbf{I}_{1}$} & \multirow{3}{*}{$\mathbf{S}_{1}$} & $\overline{H_{1}}$ & $264^{\text {hi }}$ & $234^{\mathrm{fg}}$ & $58^{\mathrm{fg}}$ & $53^{\mathrm{ef}}$ & 6.4 & 6.4 & $32^{\text {def }}$ & $32^{\text {defg }}$ & $33^{\text {cdef }}$ & $32^{\mathrm{fg}}$ \\
\hline & & $\mathrm{H}_{2}$ & $271^{\text {gh }}$ & $237^{\mathrm{fg}}$ & $61^{\mathrm{ef}}$ & $54^{\mathrm{e}}$ & 6.7 & 5.3 & $33^{\text {cdef }}$ & $31^{\mathrm{efg}}$ & $35^{\text {bcde }}$ & $35^{\mathrm{bc}}$ \\
\hline & & $\mathbf{H}_{3}$ & $289^{\mathrm{e}}$ & $239^{\mathrm{e}}$ & $62^{\mathrm{e}}$ & $55^{\mathrm{e}}$ & 6.4 & 5.5 & $34^{\text {cdef }}$ & $34^{\mathrm{de}}$ & $35^{\text {bcde }}$ & $35^{\mathrm{bc}}$ \\
\hline & \multirow{3}{*}{$\mathbf{S}_{2}$} & $\mathrm{H}_{1}$ & $308^{\mathrm{d}}$ & $243^{\mathrm{e}}$ & $74^{\mathrm{d}}$ & $78^{d}$ & 6.3 & 6.1 & $35^{\text {bcde }}$ & $33^{\text {def }}$ & $32^{\mathrm{def}}$ & $32^{\mathrm{fg}}$ \\
\hline & & $\mathrm{H}_{2}$ & $320^{c}$ & $283^{c}$ & $78^{\mathrm{d}}$ & $90^{\mathrm{c}}$ & 6.3 & 6.7 & $36^{\text {abcd }}$ & $35^{\mathrm{c}}$ & $36^{\mathrm{abc}}$ & $35^{\mathrm{bc}}$ \\
\hline & & $\mathbf{H}_{3}$ & $344^{b}$ & $294^{b}$ & $75^{\mathrm{d}}$ & $97^{\mathrm{b}}$ & 6.1 & 5.9 & $37^{\mathrm{abc}}$ & $38^{\mathrm{b}}$ & $37^{\mathrm{abc}}$ & $36^{\mathrm{b}}$ \\
\hline & \multirow{3}{*}{$\mathbf{S}_{\mathbf{3}}$} & $\mathrm{H}_{1}$ & $293^{\mathrm{e}}$ & $274^{\mathrm{d}}$ & $83^{\mathrm{c}}$ & $87^{\mathrm{c}}$ & 6.4 & 6.0 & $38^{\mathrm{ab}}$ & $37^{\mathrm{bc}}$ & $35^{\text {bcde }}$ & $35^{\mathrm{bc}}$ \\
\hline & & $\mathbf{H}_{2}$ & $322^{\mathrm{c}}$ & $297^{b}$ & $88^{\mathrm{b}}$ & $98^{\mathrm{b}}$ & 6.3 & 6.9 & $37^{\mathrm{abc}}$ & $38^{\mathrm{b}}$ & $37^{\mathrm{abc}}$ & $36^{\mathrm{b}}$ \\
\hline & & $\mathbf{H}_{3}$ & $357^{\mathrm{a}}$ & $317^{\mathrm{a}}$ & $94^{\mathrm{a}}$ & $110^{\mathrm{a}}$ & 7.0 & 7.2 & $40^{\mathrm{a}}$ & $48^{\mathrm{a}}$ & $39^{\mathrm{a}}$ & $39^{\mathrm{a}}$ \\
\hline \multirow{9}{*}{$\mathbf{I}_{2}$} & \multirow{3}{*}{$\mathbf{S}_{1}$} & $\mathrm{H}_{1}$ & $241^{\mathrm{k}}$ & $221^{\mathrm{j} k}$ & $30^{j}$ & $20^{j}$ & 6.1 & 5.0 & $22^{\mathrm{h}}$ & $23^{\mathrm{h}}$ & $31^{\mathrm{ef}}$ & $30^{\mathrm{hi}}$ \\
\hline & & $\mathrm{H}_{2}$ & $253^{i j}$ & $230^{i}$ & $34^{\mathrm{ij}}$ & $24^{\mathrm{i}}$ & 5.8 & 5.3 & $27^{\mathrm{g}}$ & $24^{\mathrm{h}}$ & $33^{\text {cdef }}$ & $32^{\mathrm{fg}}$ \\
\hline & & $\mathbf{H}_{3}$ & $262^{\mathrm{hi}}$ & $218^{\mathrm{jk}}$ & $33^{\mathrm{ij}}$ & $22^{i j}$ & 5.6 & 5.6 & $30^{\mathrm{fg}}$ & $29^{\mathrm{g}}$ & $35^{\text {bcde }}$ & $32^{\mathrm{fg}}$ \\
\hline & \multirow{3}{*}{$\mathbf{S}_{2}$} & $\mathrm{H}_{1}$ & $282^{\mathrm{ef}}$ & $197^{\mathrm{m}}$ & $35^{\mathrm{i}}$ & $25^{\mathrm{i}}$ & 6.3 & 5.2 & $32^{\mathrm{def}}$ & $31^{\text {efg }}$ & $30^{f}$ & $29^{i}$ \\
\hline & & $\mathrm{H}_{2}$ & $247^{\mathrm{jk}}$ & $227^{\mathrm{i}}$ & $46^{\mathrm{h}}$ & $50^{\mathrm{fg}}$ & 6.0 & 5.4 & $30^{\mathrm{fg}}$ & $31^{\text {efg }}$ & $36^{\mathrm{abc}}$ & $32^{\mathrm{fg}}$ \\
\hline & & $\mathbf{H}_{3}$ & $268^{\text {gh }}$ & $218^{\mathrm{jk}}$ & $57^{\mathrm{fg}}$ & $50^{\mathrm{fg}}$ & 6.5 & 5.3 & $33^{\text {cdef }}$ & $32^{\operatorname{defg}}$ & $34^{\text {bcde }}$ & $34^{\text {cde }}$ \\
\hline & \multirow{3}{*}{$\mathbf{S}_{\mathbf{3}}$} & $\mathrm{H}_{1}$ & $263^{\text {hi }}$ & $243^{\mathrm{e}}$ & $42^{\mathrm{h}}$ & $43^{\mathrm{h}}$ & 5.6 & 5.9 & $31^{\mathrm{efg}}$ & $30^{\mathrm{fg}}$ & $34^{\text {bcde }}$ & $33^{\text {def }}$ \\
\hline & & $\mathbf{H}_{2}$ & $267^{\mathrm{h}}$ & $234^{\mathrm{fg}}$ & $55^{\mathrm{g}}$ & $52^{\mathrm{ef}}$ & 6.5 & 5.5 & $32^{\mathrm{def}}$ & $31^{\mathrm{efg}}$ & $35^{\text {bcde }}$ & $34^{\text {cde }}$ \\
\hline & & $\mathrm{H}_{3}$ & $278^{\mathrm{fg}}$ & $232^{\mathrm{h}}$ & $59^{\mathrm{efg}}$ & $48^{\mathrm{g}}$ & 6.7 & 6.5 & $32^{\text {def }}$ & $34^{\mathrm{de}}$ & $36^{\mathrm{abc}}$ & $35^{\mathrm{bc}}$ \\
\hline & \multicolumn{2}{|c|}{ DMRT } & * & * & $* *$ & $* *$ & N.S. & N.S. & * & $*$ & * & * \\
\hline
\end{tabular}

Abbreviations of I, $\mathrm{S}$ and $\mathrm{H}$ and their operations as explained in Table 1.

Means followed by the same letter(s) in column are not significantly different at $\mathrm{P} \leq 0.05$

N.S. $=$ Not significantly different at $\mathrm{P} \leq 0.05$.

$*, * *=$ Significantly different at $\mathrm{P} \leq 0.05$ and $\mathrm{P} \leq 0.01$, respectively. 
Table 4. The Mean Effect of Interactions of the Applied Treatments on Yield Parameters of Wheat in Both Seasons

\begin{tabular}{|c|c|c|c|c|c|c|c|c|c|c|}
\hline \multirow{2}{*}{\multicolumn{3}{|c|}{$\begin{array}{c}\text { Treatment } \\
\text { combinations }\end{array}$}} & \multicolumn{2}{|c|}{ Biological yield (kg/ha) } & \multicolumn{2}{|c|}{ Grain yield (kg/ha) } & \multicolumn{2}{|c|}{ Straw yield (kg/ha) } & \multicolumn{2}{|c|}{ Harvest index (\%) } \\
\hline & & & $1^{\text {st }}$ Season & $2^{\text {nd }}$ Season & $1^{\text {st }}$ Season & $2^{\text {nd }}$ Season & $1^{\text {st }}$ Season & $2^{\text {nd }}$ Season & $1^{\text {st }}$ Season & $2^{\text {nd }}$ Season \\
\hline \multirow{9}{*}{$\mathbf{I}_{1}$} & \multirow{3}{*}{$\mathbf{S}_{1}$} & $\mathbf{H}_{1}$ & $7591^{\text {bcdef }}$ & $7236^{\circ}$ & $2353^{j}$ & $2301^{\mathrm{q}}$ & $5238^{\mathrm{k}}$ & $4935^{\circ}$ & $31^{\text {hi }}$ & $32^{\text {efgh }}$ \\
\hline & & $\mathbf{H}_{2}$ & $8012^{\text {abcdef }}$ & $8067^{1}$ & $2564^{\mathrm{h}}$ & $2693^{\mathrm{m}}$ & $5448^{g}$ & $5374^{1}$ & $32^{\text {gh }}$ & $33^{\text {defg }}$ \\
\hline & & $\mathbf{H}_{3}$ & $9431^{\mathrm{ab}}$ & $8415^{\mathrm{k}}$ & $3112^{\mathrm{d}}$ & $2887^{j}$ & $6319^{c}$ & $5528^{i}$ & $33^{\text {efg }}$ & $34^{\text {cdef }}$ \\
\hline & \multirow{3}{*}{$\mathbf{S}_{2}$} & $\mathrm{H}_{1}$ & $8114^{\text {abcdef }}$ & $8446^{j}$ & $2840^{\mathrm{g}}$ & $2994^{\mathrm{h}}$ & $5274^{j}$ & $5452^{j}$ & $35^{\text {cde }}$ & $35^{\mathrm{bcd}}$ \\
\hline & & $\mathbf{H}_{2}$ & $8879^{\mathrm{abc}}$ & $9818^{\mathrm{d}}$ & $3017^{\mathrm{f}}$ & $3518^{\mathrm{c}}$ & $5862^{\mathrm{e}}$ & $6300^{\mathrm{e}}$ & $34^{\text {defg }}$ & $36^{\mathrm{bc}}$ \\
\hline & & $\mathbf{H}_{3}$ & $8751^{\mathrm{abcd}}$ & $8485^{1}$ & $3326^{b}$ & $3065^{\mathrm{g}}$ & $5425^{\mathrm{h}}$ & $5420^{\mathrm{k}}$ & $38^{\mathrm{ab}}$ & $36^{\mathrm{bc}}$ \\
\hline & \multirow{3}{*}{$\mathbf{S}_{\mathbf{3}}$} & $\mathrm{H}_{1}$ & $9189^{\mathrm{abc}}$ & $10310^{c}$ & $2848^{\mathrm{g}}$ & $3312^{\mathrm{e}}$ & $6341^{\mathrm{b}}$ & $6998^{c}$ & $31^{\mathrm{hi}}$ & $32^{\text {efgh }}$ \\
\hline & & $\mathbf{H}_{2}$ & $9535^{\mathrm{abc}}$ & $11530^{b}$ & $3050^{e}$ & $3838^{b}$ & $6485^{\mathrm{a}}$ & $7692^{a}$ & $32^{\text {gh }}$ & $33^{\text {defg }}$ \\
\hline & & $\mathrm{H}_{3}$ & $9931^{\mathrm{a}}$ & $12330^{\mathrm{a}}$ & $3955^{\mathrm{a}}$ & $4660^{\mathrm{a}}$ & $5976^{\mathrm{d}}$ & $7670^{b}$ & $40^{\mathrm{a}}$ & $38^{\mathrm{a}}$ \\
\hline \multirow{9}{*}{$\mathbf{I}_{2}$} & \multirow{3}{*}{$\mathbf{S}_{1}$} & $\mathrm{H}_{1}$ & $6125^{\mathrm{f}}$ & $7042^{p}$ & $1838^{1}$ & $2052^{\mathrm{p}}$ & $4287^{\mathrm{P}}$ & $4990^{\mathrm{n}}$ & $30^{i}$ & $29^{h}$ \\
\hline & & $\mathbf{H}_{2}$ & $7730^{\text {bcdef }}$ & $9574^{\mathrm{e}}$ & $2473^{j}$ & $2725^{1}$ & $5257^{j}$ & $6849^{c}$ & $32^{\text {gh }}$ & $28^{\mathrm{h}}$ \\
\hline & & $\mathbf{H}_{3}$ & $7208^{\text {cdef }}$ & $7791^{\mathrm{m}}$ & $2561^{\mathrm{h}}$ & $2808^{k}$ & $4647^{\mathrm{n}}$ & $4983^{n}$ & $36^{\mathrm{cd}}$ & $36^{b c}$ \\
\hline & \multirow{3}{*}{$\mathbf{S}_{\mathbf{2}}$} & $\mathrm{H}_{1}$ & $6717^{\text {ef }}$ & $7743^{n}$ & $2280^{k}$ & $2654^{n}$ & $4437^{\circ}$ & $5089^{\mathrm{m}}$ & $34^{\text {defg }}$ & $34^{\text {cdef }}$ \\
\hline & & $\mathrm{H}_{2}$ & $6780^{\mathrm{def}}$ & $7265^{\circ}$ & $2507^{\mathrm{i}}$ & $2540^{\circ}$ & $4273^{p}$ & $4725^{\mathrm{p}}$ & $37^{\mathrm{bc}}$ & $35^{\mathrm{bcd}}$ \\
\hline & & $\mathbf{H}_{3}$ & $7206^{\text {cdef }}$ & $8793^{\mathrm{h}}$ & $2519^{i}$ & $3064^{\mathrm{g}}$ & $4687^{\mathrm{m}}$ & $5729^{\mathrm{h}}$ & $35^{\text {cde }}$ & $35^{\mathrm{bcd}}$ \\
\hline & \multirow{3}{*}{$\mathbf{S}_{\mathbf{3}}$} & $\mathrm{H}_{1}$ & $7353^{\text {cdef }}$ & $9349^{g}$ & $2277^{\mathrm{k}}$ & $2948^{\mathrm{i}}$ & $5076^{1}$ & $6401^{\mathrm{d}}$ & $31^{\mathrm{hi}}$ & $32^{\text {efgh }}$ \\
\hline & & $\mathbf{H}_{2}$ & $7873^{\text {bcdef }}$ & $9431^{\mathrm{f}}$ & $2577^{\mathrm{h}}$ & $3130^{f}$ & $5296^{i}$ & $6301^{\mathrm{e}}$ & $33^{\text {efg }}$ & $33^{\text {defg }}$ \\
\hline & & $\mathbf{H}_{3}$ & $8631^{\text {abcd }}$ & $9327^{g}$ & $3117^{\mathrm{c}}$ & $3465^{\mathrm{d}}$ & $5514^{f}$ & $5862^{g}$ & $36^{\mathrm{cd}}$ & $37^{b}$ \\
\hline \multicolumn{3}{|c|}{ DMRT } & $* * *$ & $* * *$ & $*$ & $*$ & $*$ & $*$ & $* *$ & $* *$ \\
\hline
\end{tabular}

Abbreviations of I, $\mathrm{S}$ and $\mathrm{H}$ and their operations as explained in Table 1.

Means followed by the same letter(s) in column are not significantly different at $\mathrm{P} \leq 0.05$.

$* * *, * * *=$ Significantly different at $\mathrm{P} \leq 0.05, \mathrm{P} \leq 0.01$ and $\mathrm{P} \leq 0.001$, respectively. 
Table 5. The Mean Temperature and Relative Humidity in the Experimental Site in Both Seasons

\begin{tabular}{|l|c|c|c|c|}
\hline \multirow{2}{*}{ Month } & \multicolumn{2}{|c|}{ Mean Temp $\left({ }^{\mathbf{0}} \mathbf{C}\right)$} & \multicolumn{2}{c|}{ Relative Humidity (\%) } \\
\cline { 2 - 5 } & $\mathbf{1}^{\text {st }}$ Season & $\mathbf{2}^{\text {nd }}$ Season & $\mathbf{1}^{\text {st }}$ Season & $\mathbf{2}^{\text {nd }}$ Season \\
\hline November & 22.1 & 24.9 & 40 & 46 \\
\hline December & 22.0 & 20.7 & 46 & 50 \\
\hline January & 19.7 & 19.2 & 44 & 51 \\
\hline February & 23.9 & 21.3 & 35 & 43 \\
\hline March & 27.3 & 26.3 & 25 & 34 \\
\hline
\end{tabular}

Figures 1 and 2 illustrate the appearance of wheat crop under the controlled treatments $\left(\mathrm{I}_{1} \times \mathrm{S}_{1} \times \mathrm{H}_{1}\right)$ and the best combination of treatments interactions $\left(\mathrm{I}_{1} \times \mathrm{S}_{3} \times \mathrm{H}_{3}\right)$, respectively. It clear that the growth and appearance of wheat crop grown under treatments interactions $\mathrm{I}_{1} \times \mathrm{S}_{3} \times \mathrm{H}_{3}$ was more better than under the controlled treatments $\left(\mathrm{I}_{1} \times \mathrm{S}_{1} \times \mathrm{H}_{1}\right)$.

Since the sand loamy soil of the study area have weakly developed profiles and a loose consistency, so the use of irrigation canal sediments as soil an amendment by incorporation with the soil this could be a good source for soil reclamation for its availability and low cost. It was clarified that application of irrigation canal sediments improved wheat productivity. Mubarak et al. (2015) concluded that, short-term application of irrigation canal sediments could be useful practice in amelioration of poor quality desert soils (Aridisols) through improving physical and chemical properties.

Figure 1. Appearance of Wheat Crop Grown under the Controlled Treatments

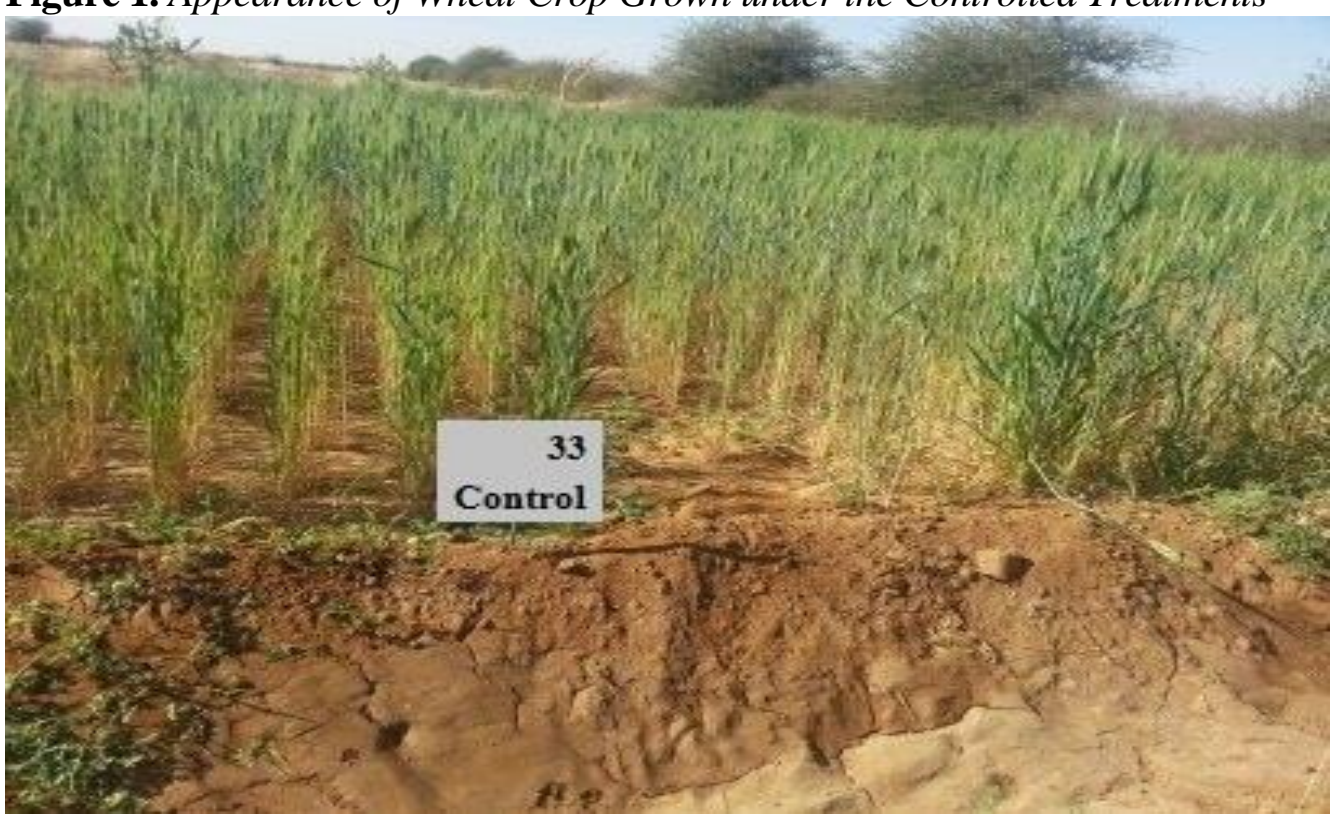


Figure 2. Appearance of Wheat Crop Grown under Application of 60 ton/ha Irrigation Canal Sediment, 4 kg/fed Humate Fertilizer and 10 Days Irrigation Interval

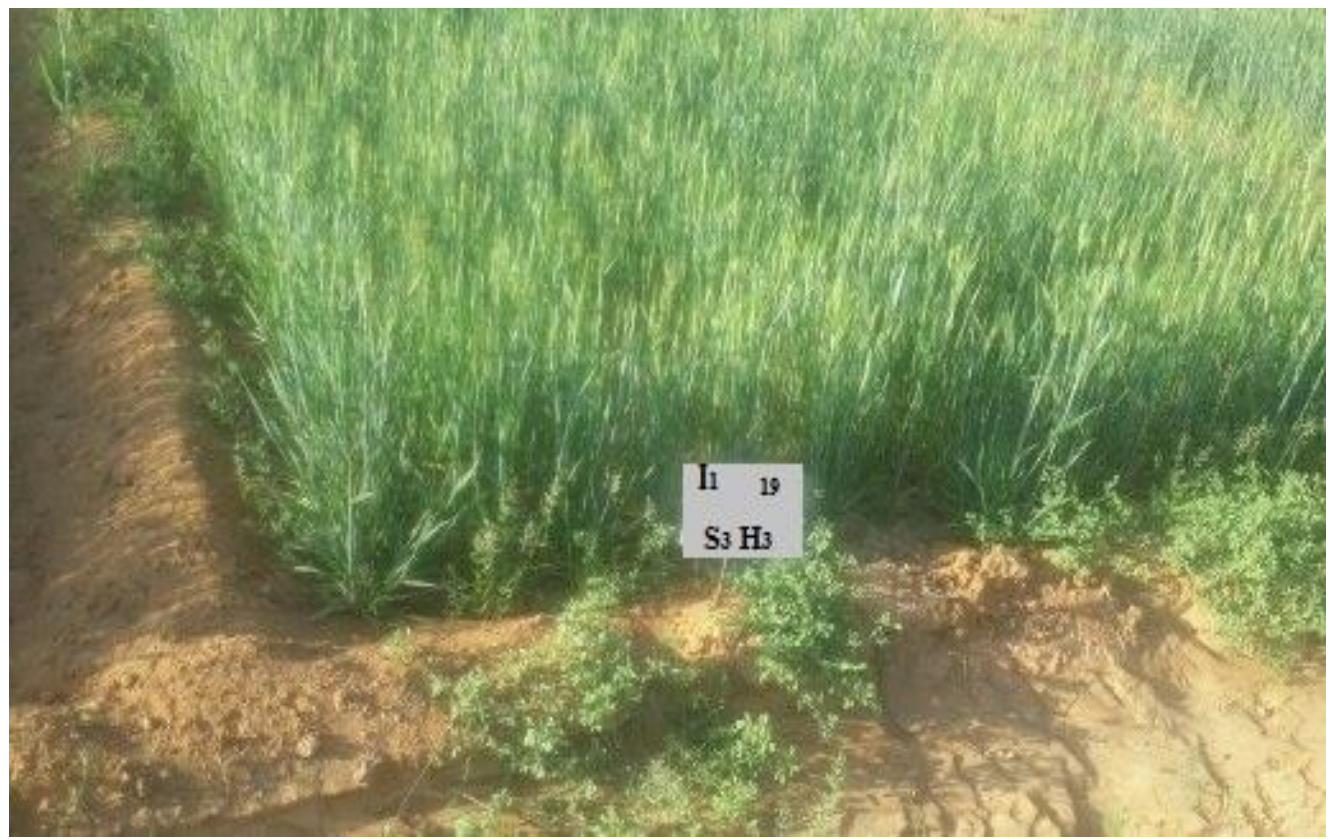

The desert plain soils of the Northern State of Sudan are characterized by high amount of sand and low chemical soil fertility and mostly are deficient in Nitrogen, Phosphorus and Organic Carbon for optimum yield production of different cultivated crops (Land and Water Research Centre 1999). Humate fertilizer, as humic acid in its solid state, is a good healthy and cheap solution for the poor and infertile soil of the study area. The results of this study showed that the application of humic acid improved growth and yield of wheat. As mentioned by Rasool et al. (2015) and Dudley (2018), humic acid is very economical product which increased the fertility status of soil; especially in light and sandy soils which typically are poor in humans, thus, provide conditions which are favourable to plant growth and ultimately increase yield of crop. Also, the results is in agreement with that of Shahryari et al. (2009) who stated that, humic substance is a beneficial natural substance for increasing the quality and the quantity of wheat. In the same manner, Babar Iqbal et al. (2016) concluded that wheat yield increased by increasing the application of humic acid. According to Petti (2004), plants grown on soils which contain adequate humin, humic acids, and fulvic acids are less subject to stress, are healthier, produce higher yields; and the nutritional quality of harvested foods and feeds are superior.

Irrigation is an expensive input, therefore, farmer, agronomist, economist and engineer need to know the response of growth and yield of wheat to irrigation. Several investigations from different parts of the world reported that growth and yield attributes of wheat; plant height, number of tillers $/ \mathrm{m}^{2}$, number of spike $/ \mathrm{m}^{2}$, spike length, number of seeds/spike, 1000-seeds weight, biological yield, grain yield, straw yield and harvest index, increased with more frequent irrigation and decrease with less frequent irrigation (Hussain et al. 2004, Zeidan et al. 2009, 
Akram 2011, El Hwary and Yagoub 2011, Seleiman et al. 2011, Ali and Ahmed 2012, Ngwako and Mashiqa 2013, Rahman 2014, Shrief and Abdel-Mohsen 2015).

\section{Conclusions}

The results obtained shown that wheat production in soil of low or marginal productivity (Aridisols) could be increased by maintenance of this soil to increase the cultivated area. In high terrace soils, as in the Northern State of Sudan, the application of sediments accumulated in irrigated canals might be a useful way to increase the wheat productivity and disposal of this sediment. Also, wheat production in poor quality desert soils could be increased by increasing the application of humate fertilizer. Furthermore, the effective and efficient use of irrigation water (less frequent irrigation) could increase the growth and yield attributes of wheat. As far as irrigation canal sediments and humate fertilizer applications and irrigation interval combination is concerned, it can be concluded that the higher values of the most growth and yield attributes of winter wheat cultivated in El Multaga soil series (Northern State of Sudan) were obtained under application of 60 ton/ha irrigation canal sediments, $4 \mathrm{~kg} / \mathrm{fed} \mathrm{humate}$ fertilizer and 10 days irrigation interval.

\section{References}

Ageeb OA (1994) Agronomic Aspects of Wheat Production in Sudan. In DA Saunders, GP Hettel (eds), Wheat in Heat- Stressed Environments: Irrigated, Dry Areas and Rice-Wheat Farming Systems, 67-74. Proceedings of the International Conference of Wheat in Hot, Dry, Irrigated Environments, 1-4 February 1993. Wad Medani, Sudan.

Ageeb OA, Elahmadi AB, Solh MB (1996) Wheat Production and Improvement in the Sudan. In MC Saxena (ed), Proceedings of the National Research Review Workshop, 27- 30 August 1995.Wad Medani, Sudan.

Akram M (2011) Growth and Yield Components of Wheat under Water Stress of Different Growth Stages. Bangladesh Journal of Agricultural Research 36(3): 455-468.

Ali AA, Ahmed SH (2012) Water Stress Effect on Yield and Water Use Efficiency of Two Wheat Varieties, 337-343. $3^{\text {rd }}$ RUFORUM Biennial Meeting, 24-28 September 2012. Entebbe, Uganda.

Almeu A, Hazem A (2011) Government of Sudan and FAO/WFP Crop and Food Security Assessment Mission to the 15 Northern States of Sudan. Retrieved from https://bit. ly/2XU8oEh.

Babiker EA, Faki H (1994) Evaluation of Farmers' Attitudes and their Effect on Wheat Productivity and Input Use in Rahad Scheme. Wad Medani, Sudan: ICARDA/ARC.

Dudley D (2018) Humate, A Farmer's Best Friend. Retrieved from https://bit.ly/2V $\mathrm{Z7g} 0 \mathrm{~F}$.

El Hwary EB, Yagoub SO (2011) Effect of Different Irrigation Intervals on Wheat (Triticum Aestivum L.) in Semi-Arid Regions of Sudan. Journal of Science and 
Technology 12(3): 75- 83.

Elquosy D (1998) Demand Management Policies, 1-8. International Conference on Water Problem in Africa, 26-27 October 1998. Cairo University, Egypt.

Erneo DB (2007) Impact of Irrigation Method and Variety on Water Requirement of Wheat (Triticum Aestivum L.) in the Upper Terrace of Northern Sudan. PhD Thesis. Sudan: University of Juba.

Farah SM, Ahmed SH, Salih AA, Ishag HM, Badr Eldin AM (1994) Effect of Skipping Irrigation at Different Developmental Stages of Wheat, 1-5. Nile Valley Regional Coordination Meeting, 1-4 October 1994. Cairo, Egypt.

Habiballa AM, Ali AM (2010) Classification of Climates Using Aridity Indices. Sudan Journal of Desertification Research 2: 62-75.

Hussain A, Chaudhry MR, Wajid A, Ahmed A, Rafiq M, Ibrahim M, Goheer AR (2004) Influence of Water Stress on Growth, Yield and Radiation Use Efficiency of Various Wheat Cultivars. International Journal of Agriculture \& Biology 6(6): 1074-1079.

Imran AA (2010) Effect of Tillage Methods, Green and Farmyard Manures on Wheat Yield and Properties of Desert Plain Soils, Northern State, Sudan. MSc Thesis. Wad Medani, Sudan: University of Gezira.

Iqbal B, Shazma A, Farjad I, Wajid A, Mohammad I, Shehryar KH (2016) Response of Wheat Crop to Humic Acid and Nitrogen Levels. EC Agriculture 3(1): 558-565.

Land and Water Research Centre (1999) Detailed Soil Survey and Land Suitability Classification of El Multaga Scheme. Wad Medani, Sudan: Agricultural Research Corporation.

Mubarak AA, Hassan AA, Ahmed IA, Eltilib AMA (2014) Use of Dry Sewage Sludge and Clay based Ameliorant for Production of Wheat (Triticum Aestivum L.) in a Desert Soil II: Effects on Yield and Nutrient Content. Sudan Journal of Desertification Research 6(1): 67-78.

Mubarak AA, Hassan AA, Ahmed IA, Eltilib AMA (2015) A Note on the Impact of Dry Sewage Sludge and Hamdab Irrigation Canal Sediment on Some Quality Attributes of an Aridisols, Northern State. Sudan Journal of Desertification Research 7(1): 132-141.

Ngwako S, Mashiqa PK (2013) The Effect of Irrigation on Growth and Yield of Winter Wheat (Triticum Aestivum L.) Cultivars. International Journal of Agriculture and Crop Sciences 5(9): 976-982.

Petti R (2004) Organic Matter, Humus, Humate, Humic Acid, Fulvic Acid and Humin: Their Importance in Soil Fertility and Plant Health. Retrieved from https://bit.ly/ 2TveUmy.

Rahman M (2014) Effects of Different Levels of Irrigation on the Yield and Yield Contributing Characters of Wheat. MSc Thesis. Bangladesh Agricultural University. Retrieved from https://bit.ly/2HeH7aD.

Rasool GH, Wahla AJ, Nawaz M, Abdur Rehman M (2015) Determination and Evaluation of the Effect of Different Doses of Humic Acid on the Growth and Yield of Wheat (Triticum Aestivum L.). Journal of Agriculture and Veterinary Science 8(2): 5-7.

Seleiman M, Abdel-aal S, Ibrahim M, Zahran G (2011) Productivity, Grain and Dough Quality of Bread Wheat Grown with Different Water Regimes. Journal of AcroCrop Science 2(1): 11-17.

Shahryari R, Gadimov A, Gurbanov E, Valizade M (2009) Application of Potassium Humate to Wheat for Organic Agriculture in Iran. Asian Journal of Food and Agro-Industry 2(Special Issue-ref. 12): 164-168.

Shrief SA, Abdel-Mohsen AA (2015) Regression Models to Describe the Influence of 
Different Irrigation Regimes on Grain Yield and Water Use Efficiency in Bread Wheat. Advance in Agriculture and Biology 4(1): 39-49.

Tester CF (1990) Organic Amendment Effects on Physical and Chemical Properties of a Sandy Soil. Soil Science Society of America Journal 54(3): 827-831.

Zeidan EM, Abd El-Hameed IM, Bassiouny AH, Waly AA (2009) Effects of Irrigation Intervals, Nitrogen and Organic Fertilization on Yield, Yield Attributes and Crude Protein Content of Some Wheat Cultivars under Newly Reclaimed Saline Soil, 298307. $4^{\text {th }}$ Conference on Recent Technologies in Agriculture. Retrieved from https://bit.ly/2CfMuCc. 